\title{
INTRODUCTION TO THE SYMPOSIUM ON UNILATERAL TARGETED SANCTIONS
}

\author{
Anne van Aaken*
}

As a decentralized system, international law since World War II has always been effectuated in a myriad of ways: via UN-backed or unilateral measures, military and nonmilitary measures, embargos or targeted sanctions—and of course national legal orders. This symposium concentrates on targeted sanctions adopted by states without multilateral institutional approval. Such measures are controversial and were embryonic when the International Law Commission (ILC) drafted the Articles on the Responsibility of States for Internationally Wrongful Acts (ARSIWA). ${ }^{1}$ Today, unilateral targeted sanctions present a dilemma of growing significance: On the one hand, they have become a preferred choice for states because they are not as costly as comprehensive embargoes for the industry of the targeting state; impose fewer costs on civilian populations in terms of life, health, and wellbeing; and provide the targeting state with a means of enforcing international law. On the other hand, these sanctions are of uncertain legality and at risk of potential misuse. As a result, countries that use them to enforce international law may themselves face the risk of responsibility under international law. In addition, an uneven distribution of power to impose unilateral targeted sanctions is cementing de facto inequality between states. Furthermore, the effectiveness of targeted sanctions is at best unclear and at worst unsupported in empirical studies. ${ }^{2}$ Unless sanctions are seen as merely a form of expressive law, ${ }^{3}$ such cross-cutting practical and legal implications put the whole exercise into question.

\section{Outcasting Without Clear Rules}

One mode of decentralized enforcement of international law is treaty-based "outcasting" - that is, denying the disobedient state or its citizens and corporations the benefits of social cooperation and membership. ${ }^{4}$ Outcasting does not rely on physical force to maintain order and includes as targets not only states but also market participants and individuals. It is used quite effectively in treaty law (e.g., the Montreal Protocol on Substances that Deplete the Ozone Layer, ${ }^{5}$ the Convention on International Trade in Endangered Species of Wild Fauna and

* Doctorate in Law, Master in Economics, Alexander von Humboldt Professor of Law and Economics, Legal Theory, Public International Law and European Law, University of Hamburg, Germany.

${ }^{1}$ Int'l Law Comm'n, Articles on the Responsibility of States for Internationally Wrongful Acts, with Commentaries, 2 Y.B. INT'L L. Comm'N 31, 75, 129 para. 8, 137 para. 3 \& art. 54 (2001) [hereinafter ARSIWA and ARSIWA Commentary].

${ }^{2}$ For a comprehensive overview on the effects of comprehensive as well as targeted sanctions, see Daniel W. Drezner, Sanctions Sometimes Smart: Targeted Sanctions in Theory and Practice, 13 INT'L STUD. REv. 96 (2011).

${ }^{3}$ Even if they do not cause a change in state behavior, sanctions may still be effective as expressions of what other states consider to be the law.

${ }^{4}$ Oana A. Hathaway \& Scott Shapiro, Outcasting: Enforcement in Domestic and International Law, 212 YALE L.J. 252 (2011). In international law, this mechanism is used pervasively.

${ }^{5}$ Montreal Protocol on Substances that Deplete the Ozone Layer, Sept. 16, 1987, 1522 UNTS 29. Article 4 bans the import of the controlled substances listed in the Annexes from nonparties.

The American Society of International Law and Anne van Aaken (C) 2019. This is an Open Access article, distributed under the terms of the Creative Commons Attribution licence (http://creativecommons.org/licenses/by/4.0/), which permits unrestricted re-use, distribution, and reproduction in any medium, provided the original work is properly cited. 
Flora, ${ }^{6}$ and the Basel Convention on the Control of Transboundary Movements of Hazardous Wastes and Their Disposal $^{7}$ ) and soft law (e.g., the Kimberly Process for Conflict Diamonds and the Financial Action Task Force on money laundering and terrorist financing). In these areas, noncompliant states (and their economic actors) are shut out of the club, with damaging consequences, but can be (re)admitted — and the rules are comparatively clear.

Targeted sanctions can be viewed as a means of non-treaty-based outcasting, since they prevent individuals and corporations from obtaining the benefits of free contracting and interfere with property rights (by freezing assets and punishing counterparties to contracts), expose both types of actors to blacklisting, and subject individuals to travel bans. The application of targeted sanctions by major powers has become a primary means of deterring and punishing noncompliance with international law. This may be necessary and beneficial in a decentralized legal system if used responsibly by targeting states. ${ }^{8}$

Yet unilateral targeted sanctions carry risks. Because they are not treaty-based, there are no clear criteria to govern their use, which creates legal uncertainty and the potential for misuse. As the ILC has explained, "Like other forms of self-help, countermeasures are liable to abuse and this potential is exacerbated by the factual inequalities between States." 9 This is a fortiori the case for noninjured states taking measures. Crucial for the debate on targeted sanctions are thus the contours of their legality under international law, a question greatly in need of clarification. The uncertainty includes (1) whether targeted sanctions are lawful at all, (2) the use of national security as justification, and (3) the permissible extraterritorial reach of these measures.

\section{Questions Under the Law of State Responsibility}

The first problem is that unilateral targeted sanctions may be incompatible with ARSIWA. Whereas "retorsions" are measures of discourtesy or unfriendliness that fall short of violating a rule of international law, countermeasures are per se unlawful if the targeting state cannot justify them by identifying a violation of international law by the targeted state (or its government officials). Although the legality of sanctions must be judged on a case-by-case basis, several crucial variables in the legal framework require clarification, only some of which will be discussed here.

First is the distinction between injured and noninjured states. Under Article 42 of ARSIWA, an injured state can without doubt undertake countermeasures if a breached obligation is owed to that state individually or, in certain cases, to a group of states that includes that state or to the community as a whole. For example, countermeasures are permitted in the event of a material breach of a treaty where each party's performance is effectively conditioned upon and requires the performance of the others. ${ }^{10}$ But Article 42 was meant to be narrowly construed, and is therefore unlikely to support the use of unilateral targeted sanctions in cases where the targeting state has acted without first suffering a clear injury. ${ }^{11}$ It is thus crucial to determine whether a state is really injured not only in its interests but legally.

\footnotetext{
${ }^{6}$ Convention on International Trade in Endangered Species of Wild Fauna and Flora, Mar. 3, 1973, 27 U.S.T. 1087,993 UNTS 243. Articles III, IV, and V regulate the trade in endangered species differently depending on how endangered the species is. Without import and export certificates, no trade can take place.

${ }^{7}$ Basel Convention on the Control of Transboundary Movements of Hazardous Wastes and Their Disposal, Mar. 22, 1989, 1673 UNTS 57. Article 4 stipulates that hazardous waste may not be exported to Antarctica, to a state not party to the Convention, or to a party having banned the import of hazardous wastes.

${ }^{8}$ For a discussion on the different positive functions of unilateralism aside from enforcement, see Monica Hakimi, Unfriendly Unilateralism, 55 HaRv. INT'L L.J. 105 (2014).

${ }^{9}$ ARSIWA Commentary, supra note 1, at 128 para. 2.

${ }^{10}$ ARSIWA, supra note 1, art. 42(a).

${ }^{11} \underline{I d}$. art. 42 \& 119 para. 13. But see Christian Tams, Enforcing Obligations Erga Omnes in International Law (2010) (suggesting that nonforcible countermeasures in case of the violation of an erga omnes obligation are allowed under conditions analogous to those
} 
Second, the legal entitlements of noninjured states also need clarification. Here practice deviates from ARSIWA. If the targeting state is not injured in the sense of Article 42, then Article 48 of ARSIWA applies. This provision covers measures taken in the collective interest and thus enables a state invoking the responsibility of the targeted state to act not in its individual capacity by reason of having suffered injury, but as a member of a group of states to which an obligation is owed (erga omnes partes) or the international community as a whole (erga omnes). ${ }^{12}$ In terms of what noninjured states can demand from a violating state, Article 48 gives rise to a more limited range of rights as compared to those of injured states under Article 42: ${ }^{13}$ Noninjured states are entitled to request cessation of the wrongful act and, if the circumstances require, assurances and guarantees of nonrepetition under Article 30. In addition, they can claim from the responsible state reparation on behalf of the injured state, if any, or the beneficiaries of the obligation breached. But sanctions are not an enumerated option. As the ILC writes: "At present, there appears to be no clearly recognized entitlement of States referred to in article 48 to take countermeasures in the collective interest." 14 Therefore, any unilateral (targeted) sanctions can only be retorsions, not countermeasures.

These uncertainties are significant because ever more targeted sanctions nowadays are adopted by noninjured states rather than as countermeasures by injured states under Article 42. For example, U.S. sanctions against Venezuela and Iran (assuming that Iran has not violated its international obligations vis-à-vis the United States) fit this description. A fortiori, the limitations on countermeasures taken under Article 42 must also apply to measures taken under Article 48. Since targeted sanctions are often directed against individuals (not only against businesses), obligations for the protection of fundamental human rights must be respected, next to the other requirements stated in ARSIWA. ${ }^{15}$

This leads to a fundamental tension between the legal requirements, evolving practice, and the effectiveness of the measures. Because economic embargoes of states have been found to hurt those whom they aim to protect - i.e., civilian populations ${ }^{16}$ — and may even result counterproductively in a rallying-around the flag, solidarity with the elite, and enrichment of their sympathizers, ${ }^{17}$ targeted sanctions seem to be an adequate and proportionate alternative. Still, if those measures are taken under Article 48, they are often unlawful. They might also violate the human rights of the targets.

\section{The Use of National Security as Justification}

The circumstances in which targeted sanctions are used may also be problematic. Geoeconomics-that is, the use of economic tools to advance geopolitical objectives—is on the rise. ${ }^{18}$ Sanctions are one important part of this

applying to a state specially affected by a breach); Institute de droit international, Resolution on Obligations and Rights Erga Omnes in International Law art. 5(3), IDI Res. I/2005 (2005), 71(2) Ann. IDI 286 (same).

12 ARSIWA, supra note 1 , art. 48 \& 126 para. 1.

${ }^{13} I d$., art. $48 \& 127$ para. 11.

${ }^{14} I d$., art. $54 \& 139$ para. 6.

15 ARSIWA, supra note 1, art. 50.1(b).

16 See UN Secretary-General, Supplement to an Agenda for Peace: Position Paper of the Secretary-General on the Occasion of the Fiftieth Anniversary of the United Nations, UN Doc. A/50/60-S/1995/1, at para. 70 (Jan. 3, 1995). With respect to Syria, see, for example, Idriss Jazairy (Special Rapporteur on the Negative Impact of Unilateral Coercive Measures on the Enjoyment of Human Rights), Report of the Special Rapporteur on the Negative Impact of Unilateral Coercive Measures on the Enjoyment of Human Rights on His Mission to the Syrian Arab Republic, UN Doc. A/HRC/39/54/Add.2 (Sept. 11, 2018).

${ }^{17}$ Cf. Alexandra Hofer, The Efficacy of Targeted Sanctions in Enforcing Compliance with International Law, 113 AJIL UnBound 163 (2019); Drezner, supra note 2.

18 J. Mark Munoz, Advances in Geoeconomics (2017). 
development. States increasingly employ them in the name of national security (and not necessarily for the enforcement of international law). However, national security may be and often has been interpreted in a self-serving manner-from the alleged threat of Belorussia to U.S. security interests ${ }^{19}$ to the threat to French national security from a yogurt company falling into foreign hands. ${ }^{20}$ In conjunction with (self-judging) invocations of national security concerns in the context of international trade and investment law, this practice turns international law into Swiss cheese by enabling states to escape international obligations through purported national security objectives. This puts the international rule of law at risk.

\section{The Permissible Degree of Extraterritorial Reach}

Connected to the phenomenon of geoeconomics is the question of power in international relations and the reach of targeted sanctions. Clearly, only economically powerful states can use the sanctions mechanism, thus cementing power asymmetries between countries. (Who would care about Nauru imposing sanctions?) The United States is in a unique position to impose sanctions via not only markets for goods and services but also the financial market, due to the still-prevalent dollarization of the world economy. ${ }^{21}$ Indeed, U.S. sanctions are uniquely damaging because they can cause extraterritorial effects by forcing all transactions based on dollars to cease and all multinational companies to either comply or face secondary sanctions in the form of U.S. fines. Paying large fines, which can exceed US\$1 billion, has often been the only way for non-U.S. companies finally to settle accusations of sanctions violations. Secondary sanctions can also be used to make economic gains and acquire competitive advantages for the targeting country's own firms. ${ }^{22}$ But secondary sanctions are of questionable legality under international law, and the precise extent to which states can otherwise regulate foreign conduct is an issue of uncertainty.

\section{The Essays in this Symposium}

The contributions of this AJIL Unbound symposium deal with many of these questions. Antonios Tzanakopoulos of the University of Oxford discusses in detail the legality of targeted and unilateral sanctions, including with a view to human rights limitations on the basis of ARSIWA. ${ }^{23} \mathrm{He}$ concludes that secondary sanctions affecting economic operators in third states are especially problematic and not legally justified.

Devika Hovell of the London School of Economics analyzes the preconditions for the legality of targeted sanctions, giving an overview of the rise of sanctions imposed in parallel to or independently of UN Security Council Sanctions under Chapter VII. ${ }^{24}$ She differentiates between UN-authorized sanctions, sanctions taken by international organizations, legitimate countermeasures, and unilateral coercive measures, ${ }^{25}$ and contends that many uses of unilateral sanctions are either unregulated or based on questionable legality.

David S. Cohen and Zachary K. Goldman, lawyers at WilmerHale and former U.S. Treasury Department officials, argue that there are two good reasons why unilateral coercive sanctions as a tool of foreign policy risk

\footnotetext{
19 See Devika Hovell, Unfinished Business of International Law: The Questionable Legality of Autonomous Sanctions, 113 AJIL UNBOUND 140 (2019).

${ }^{20}$ Jo Wrighton, Paris Leaps to Defense of Danone Against Pepsi, WALL ST. J. (July 21, 2005).

21 See Joshua P. Zoffer, The Dollar and the United States' Exorbitant Power to Sanction, 113 AJIL UnBound 152 (2019).

${ }^{22}$ Cf. How the American Takeover of a French National Champion Became Intertwined in a Corruption Investigation, ECONOMIST (Jan. 17, 2019) (discussing the takeover of parts of Alstom by GE).

23 Antonios Tzanakopoulos, State Responsibility for "Targeted Sanctions", 113 AJIL Unbound 135 (2019).

${ }^{24}$ Hovell, supra note 19.

${ }^{25}$ Id. at 140 .
} 
management are not only here to stay but also advantageous in comparison to sanctions approved by international organizations. ${ }^{26}$ First, they allow countries to defend their (sometimes unique) sovereign interests, especially when the UN Security Council is not acting (mostly due to a veto by a permanent member). Second, if they are to be implemented effectively, targeted sanctions require highly complex administrative work that is not easily undertaken by many states, let alone the United Nations, which must rely on national administrative competences. Furthermore, and specific to the United States, the dollarization of the world economy makes sanctions effective and available over the long term.

Joshua Zoffer, a J.D. candidate at Yale Law School, discusses the ability of the United States to impose damaging sanctions unilaterally and with extraterritorial effect due to the dollarization of the world economy. ${ }^{27}$ The United States has been a prolific sanctioner in recent years. Zoffer cautions about the risk of backlash by other states, as seen in Chinese efforts to challenge the dollar's key currency role through various means, including the internationalization of the renminbi and the creation of alternative financial and payments infrastructure that would replace the Worldwide Interbank Financial Telecommunication (SWIFT). Backlash may also be seen in the European Union's recent creation of a special-purpose vehicle to shield European firms from U.S. secondary sanctions pertaining to Iran and thus enable these firms to circumvent the sanctions. ${ }^{28}$

Elena Chachko, an S.J.D. candidate at Harvard Law School, examines the human rights implications of targeted sanctions in the U.S. context. ${ }^{29}$ She argues that current U.S. designation practices can be reconciled with international standards. However, she also notes that a more robust conclusion about the practices' compatibility with international human rights law would require more information on the application of designation procedures in individual cases and the extent to which the administrative process available to designated persons offers them a genuine opportunity to challenge their designation.

Alexandra Hofer, a Ph.D. candidate in Public International Law at Ghent University, takes a fresh look at the efficacy of sanctions, relying on social science insights. ${ }^{30}$ She examines the consequences of sanctions for the behavior of the target, including its government and population, focusing on the effects of coercion and stigmatization. She draws on social-psychological insights to determine not only whether sanctions work but how they work (or do not).

The sanctioning dilemma in international law is here to stay. Does that imply that the rising unilateralism of targeted sanctions is to be welcomed? It may well provoke a backlash, especially if sanctions are not viewed as legal and legitimate by the community of states but as self-serving and geoeconomically motivated. This risks putting the international community between Scylla_limiting the sanctioning of international law violations by disempowering states with sufficient power to sanction—and Charybdis—accepting potentially self-serving unilateralism, the extraterritoriality of sanctions, and human rights violations without due access to justice. The way forward seems to lie in legal clarifications by courts and/or international organizations, which could reduce the shades of legal gray that currently allow for self-serving uses of sanctions for violations of international law.

${ }^{26}$ David S. Cohen \& Zachary K. Goldman, Like it or Not, Unilateral Sanctions Are Here to Stay, 113 AJIL UnBound 146 (2019).

27 Zoffer, supra note 21.

28 The Instrument in Support of Trade Exchanges (INSTEX) acts as a sort of Euro-denominated clearing house for Iran to conduct trade with European companies. In effect, INSTEX works as a barter arrangement operating outside of the U.S.-dominated global financial system.

${ }^{29}$ Elena Chachko, Due Process Is in the Details: U.S. Targeted Economic Sanctions and International Human Rights Law, 113 AJIL UnBound 157 (2019).

${ }^{30}$ Hofer, supra note 17. 